\title{
UNIVERSITYOF
}

FORWARD

THINKING

WESTMINSTER用

WestminsterResearch

http://www.westminster.ac.uk/westminsterresearch

Nagaland: Borders, Boundaries, Belonging: Contested spaces and disputed narratives

Mccauley, C.

This is an author edited version of the accepted manuscript of an article published in the Journal of Illustration, 3 (1), 121-136, 2016. The final definitive version is available online at: https://dx.doi.org/10.1386/jill.3.1.121 1

The WestminsterResearch online digital archive at the University of Westminster aims to make the research output of the University available to a wider audience. Copyright and Moral Rights remain with the authors and/or copyright owners.

Whilst further distribution of specific materials from within this archive is forbidden, you may freely distribute the URL of WestminsterResearch: ((http://westminsterresearch.wmin.ac.uk/).

In case of abuse or copyright appearing without permission e-mail repository@westminster.ac.uk 


\title{
VISUAL ESSAY
}

CHRISTINE MCCAULEY

University of Westminster

\section{NAGALAND: Borders, Boundaries, Belonging: Contested spaces and disputed narratives}

\begin{abstract}
In 2011 I travelled to three of the 'Seven Sister'states of old Assam, Nagaland, Meghalaya \& Assam. My journey to this remote and politically sensitive region, bordering Chinese occupied Tibet, Bangladesh and Myanmar was prompted by my father's experiences in the region during WW2 in the Burma Campaign and brought into sharp relief on-going themes in my work, the impact the past has on the present, the relationship of time and place, identity and memory and the transcultural experiences caused by war, colonisation and migration. The drawings I made on location, the objects I collected and the notes and photographs I took formed the basis of the bookwork: NAGALAND borders boundaries belonging. When making the finished work the material quality of the object and the processes by which it was made become very important. The historical resonance of the medium and the time consuming nature of the process reflect the embedding of form and idea, and paid homage to the material culture of the Naga hill tribes. The bookwork was hand-bound, handset and printed by letterpress. Some spreads were printed in 6 colours and the book took over a year to produce. I see my practice as echoing that of generations of Lady travellers; embracing the need to journey, be in a liminal space, to have a plan but not be afraid to divert from it. To be alone, take a sketchbook and make images is, for me, the definition of the itinerant illustrator; one who travels widely in geographic space, visual forms and ideas, in order to get lost and find the unlooked for.
\end{abstract}




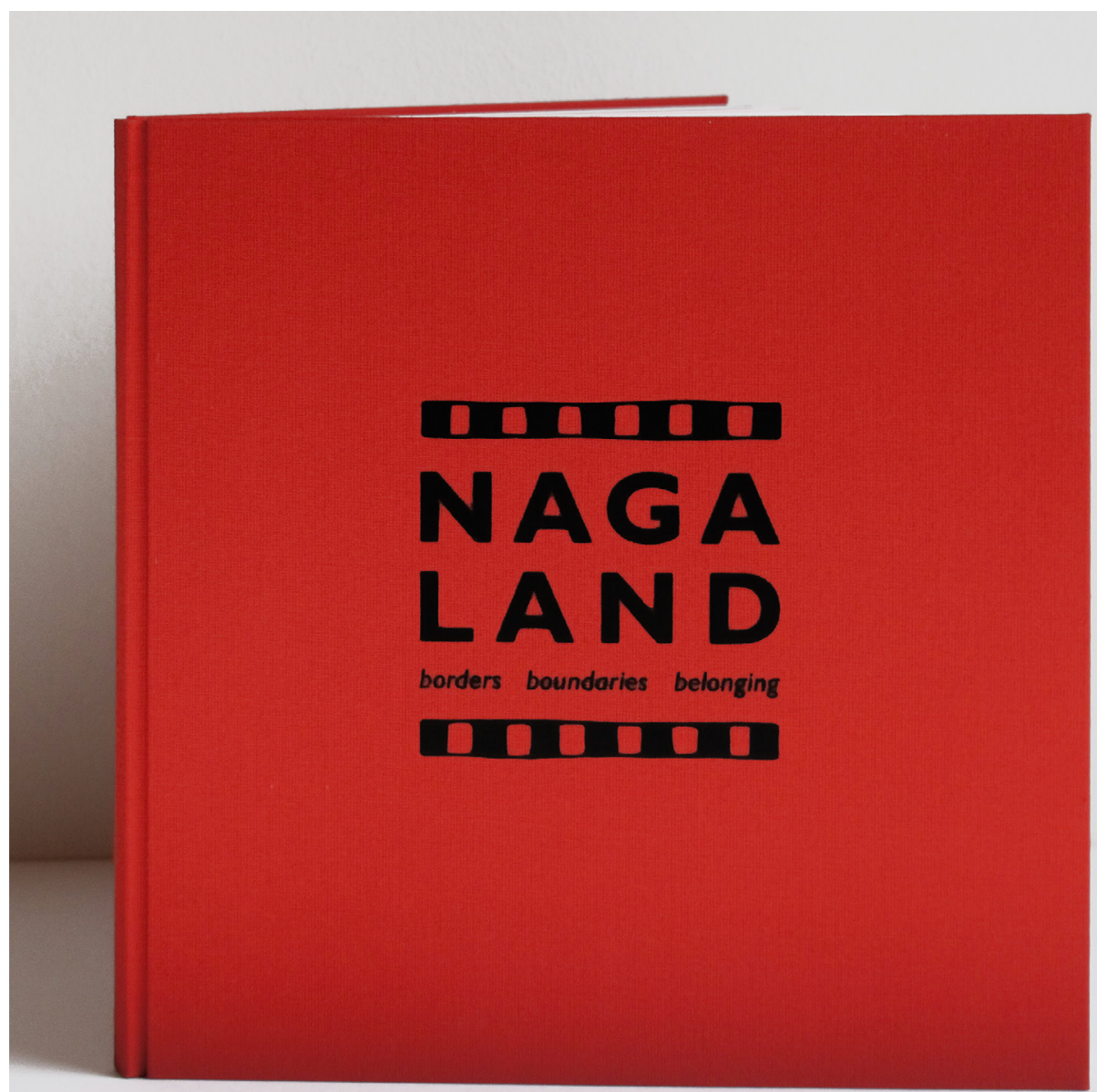

Figure 1: Cover. Title \& Naga traditional motif. Black foil blocking onto red book cloth. 


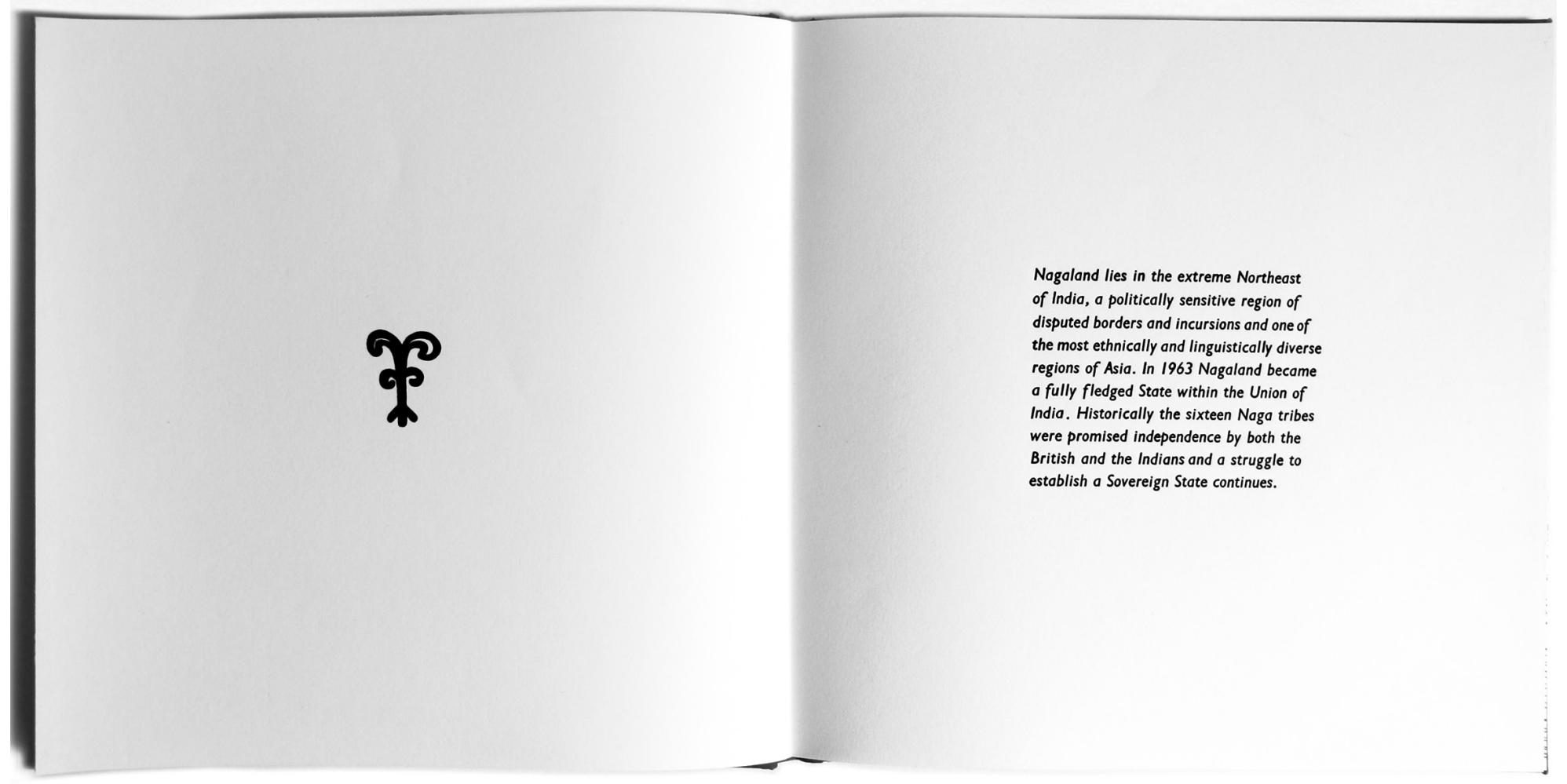

Figure 2: Pages $6 \&$ 7. Naga traditional motif \& hand set type. 


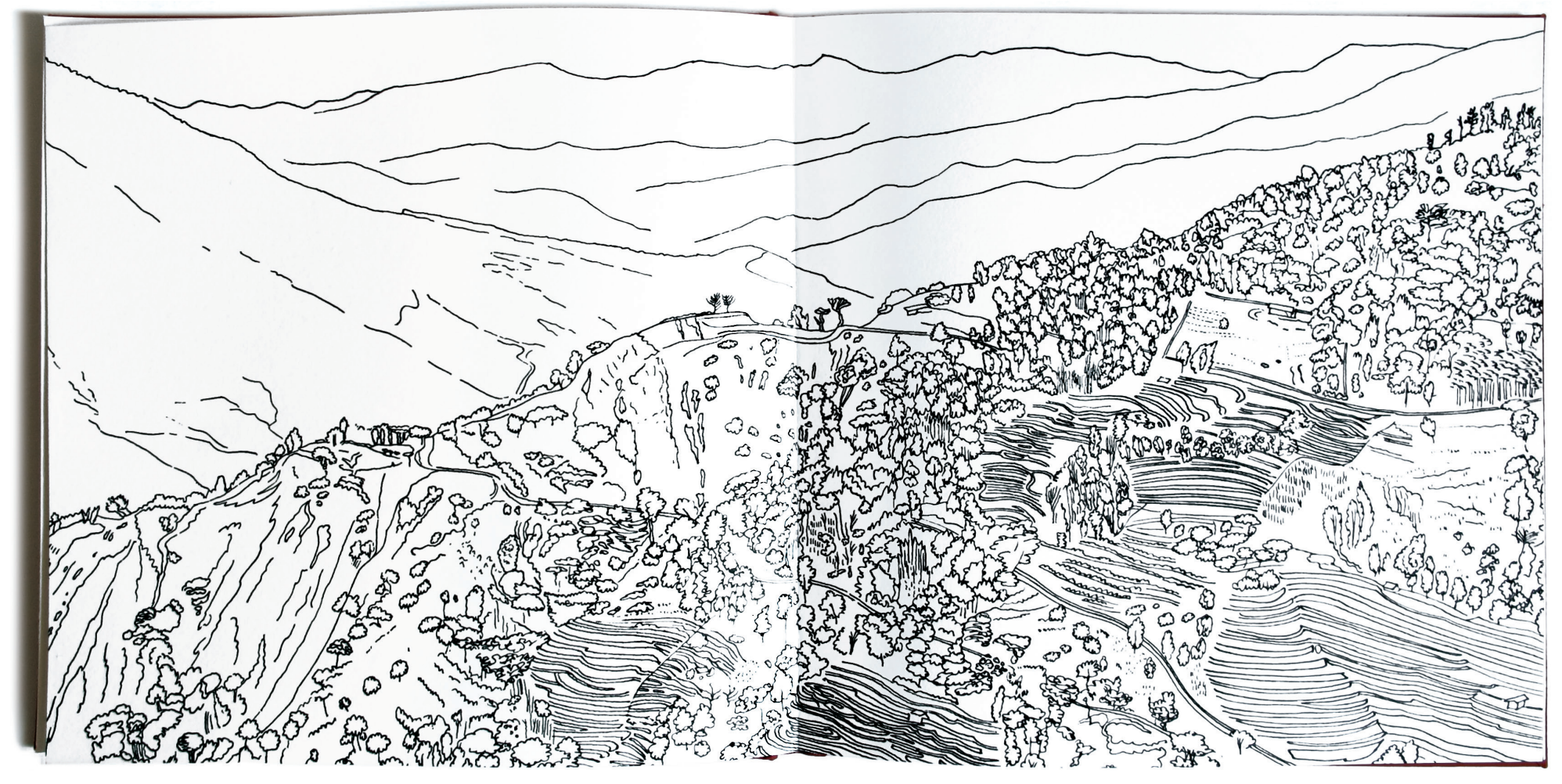

Figure 3: Pages 8 \& 9. The view from Khonoma. Polymer plate. 

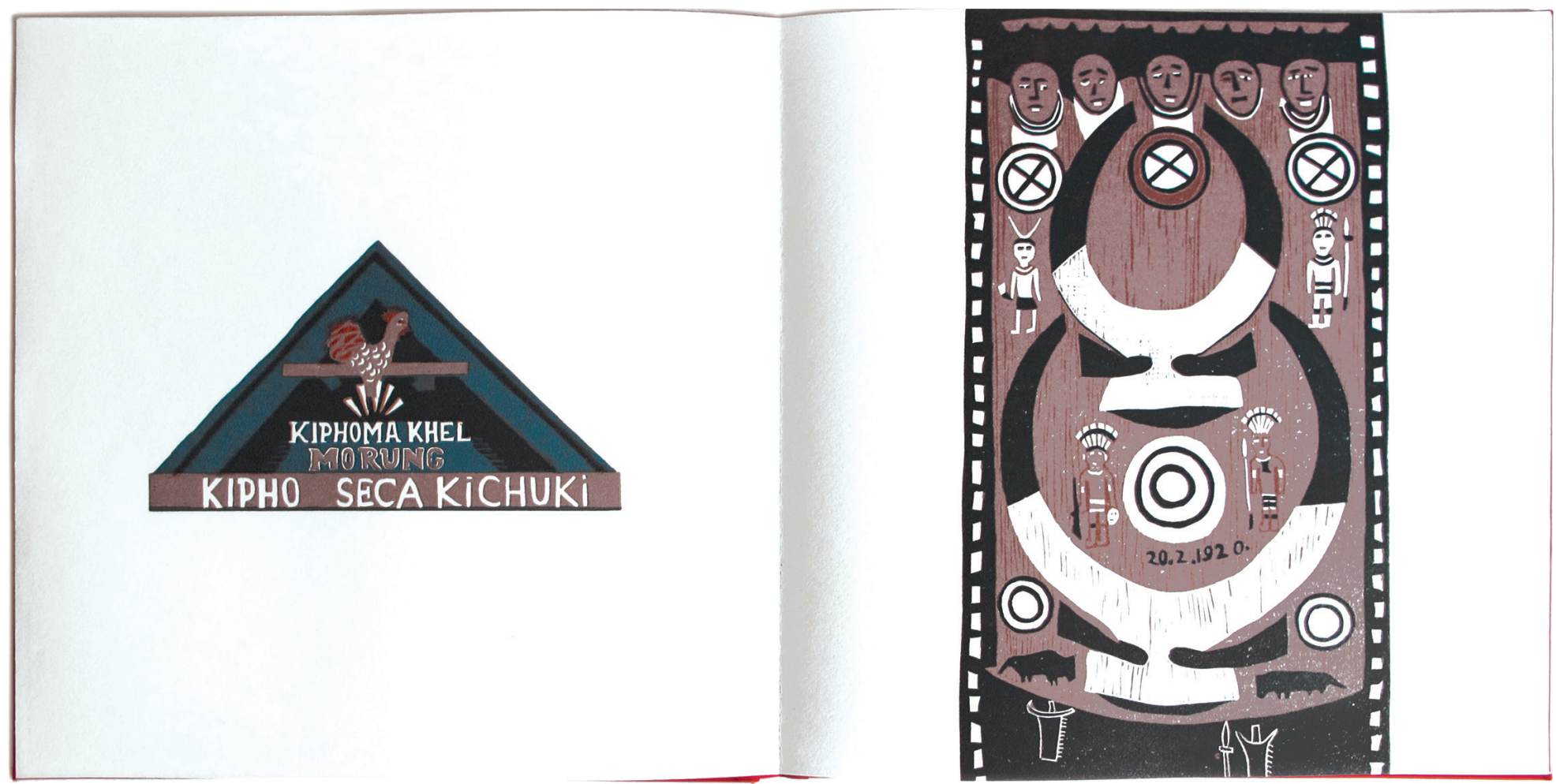

Figure 4: Pages 10 \& 11. Lettering on a Khel and the door to Kigwema. Three colour lino cut 

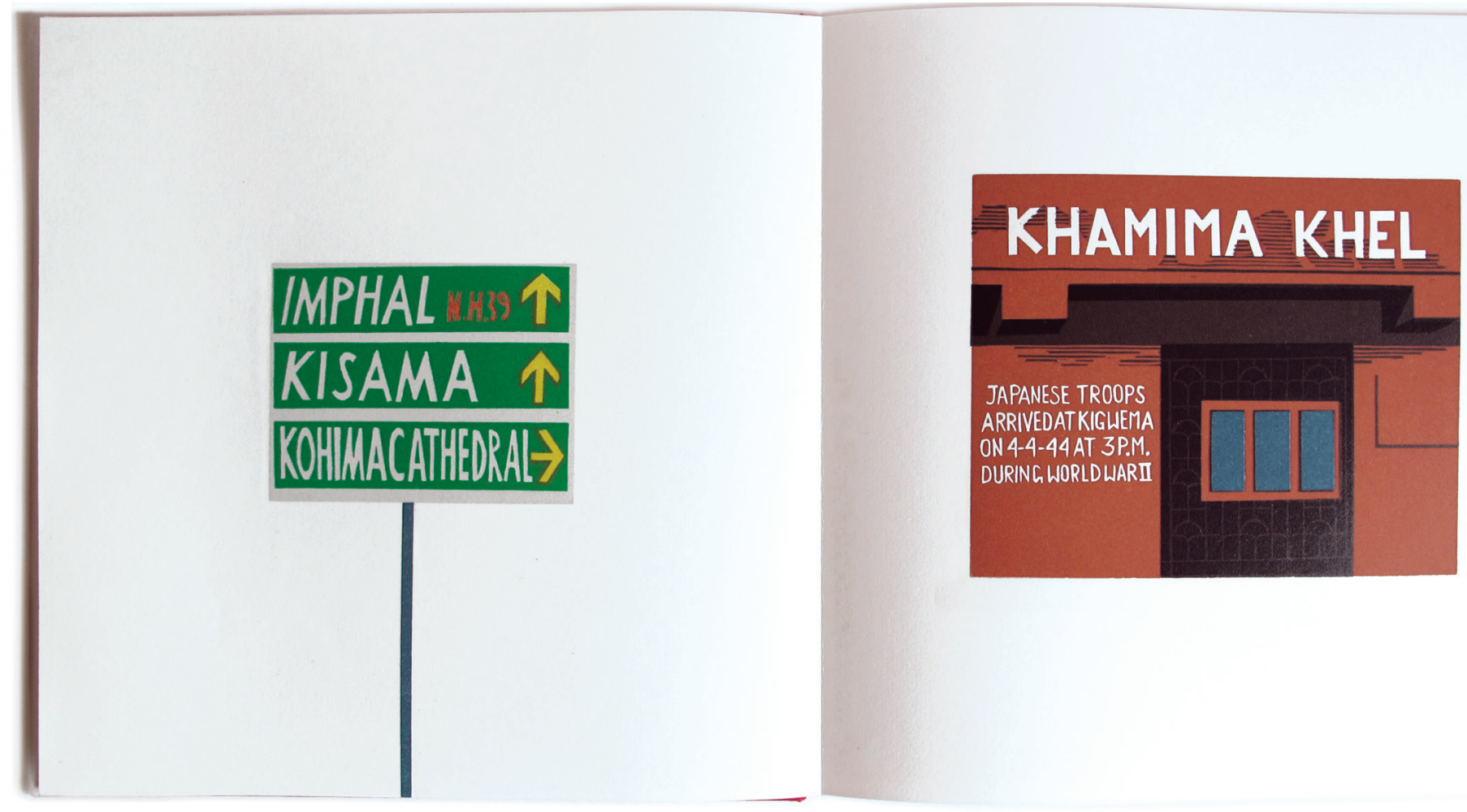

Figure: Pages 12 \& 13. Road sign \& lettering on a Khel in Kigwema. Six colour lino cut. 


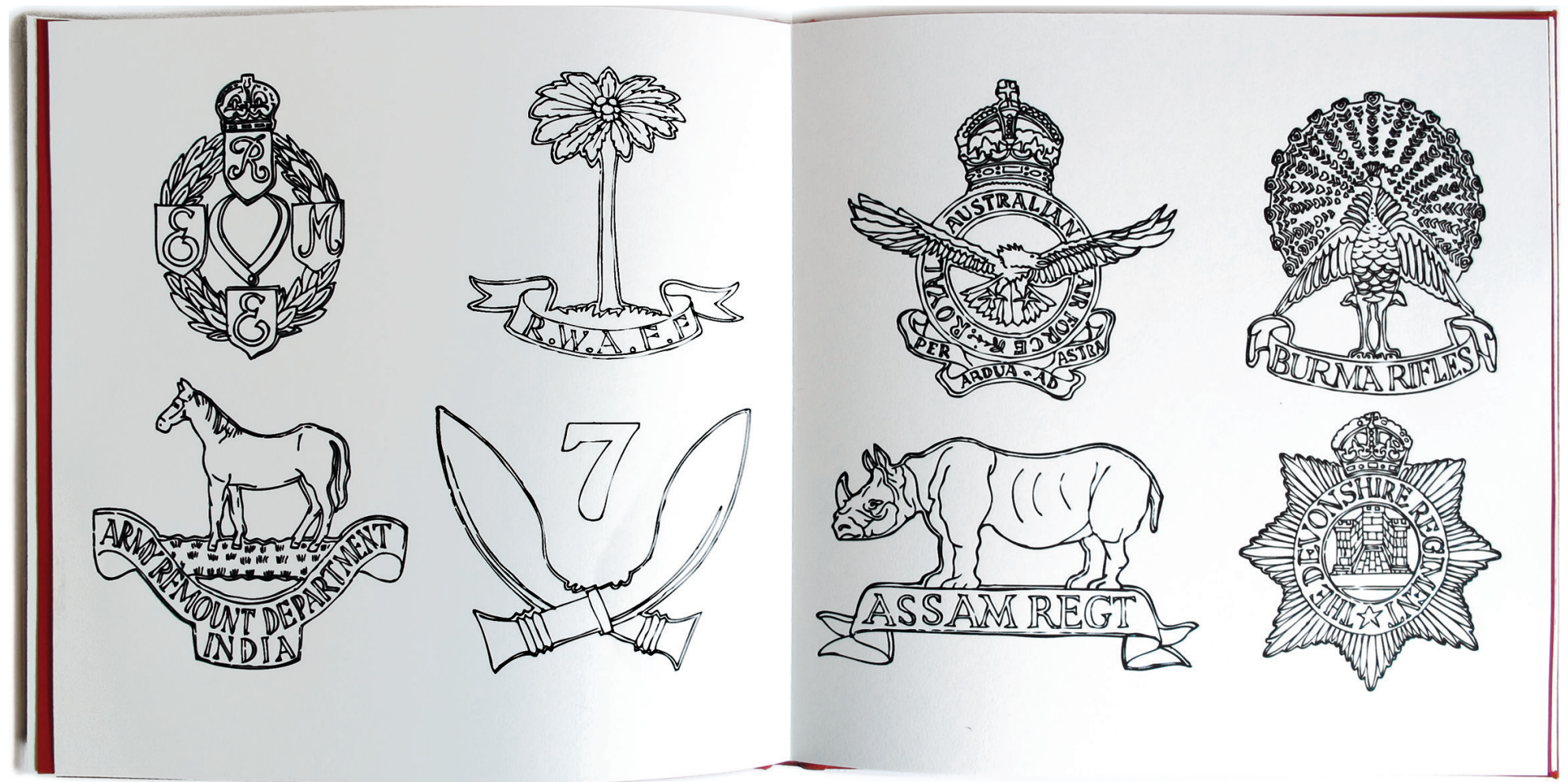

Figure 6: Pages 16 \& 17. Regimental Badges on grave stones in Kohima War Cemetery. Polymer plate 

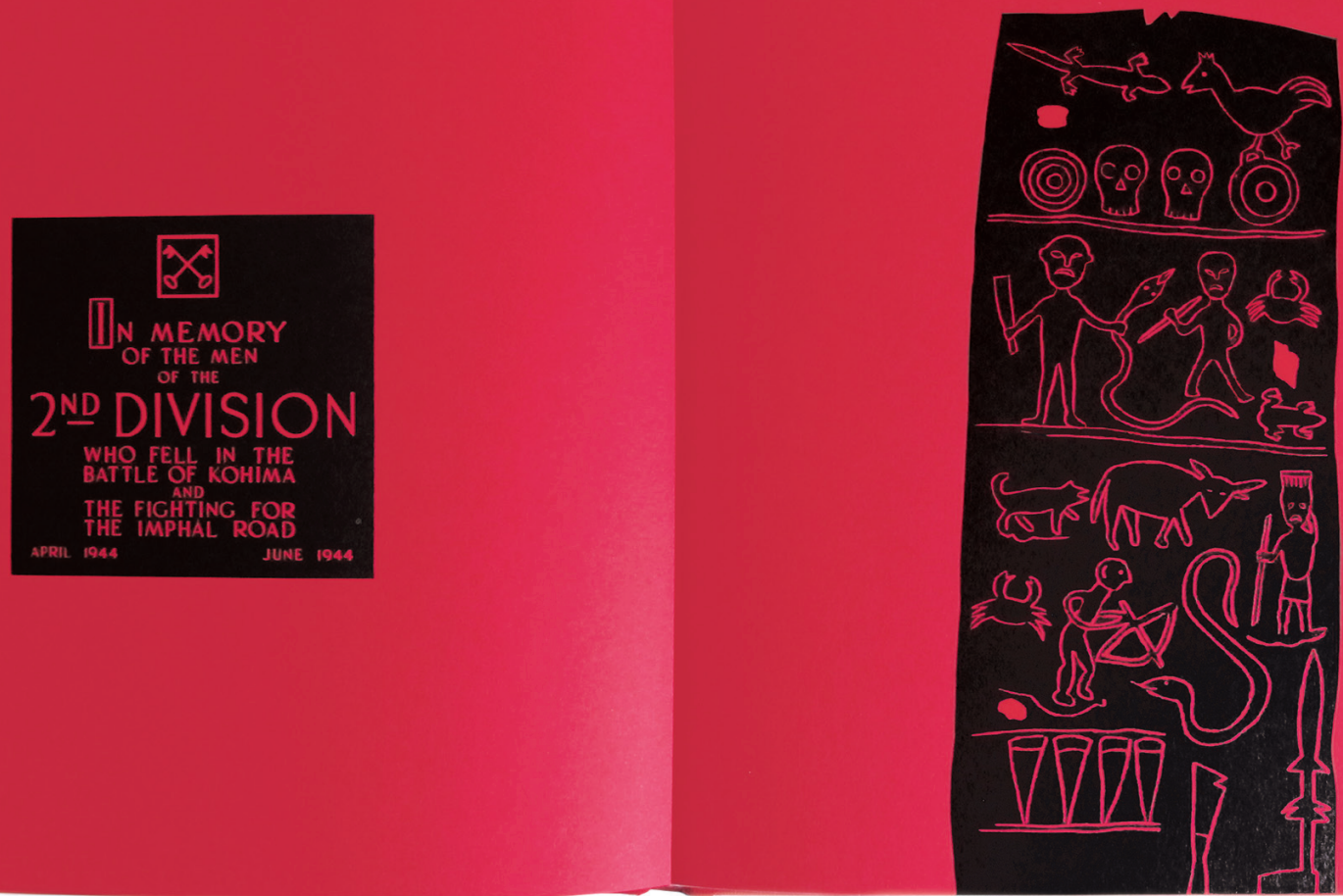

Figure 7: Pages 18 \& 19. A commemorative plaque in Kohima War Cemetery \& a Naga shield. Magnesium plate \& lino cut printed black on red paper 


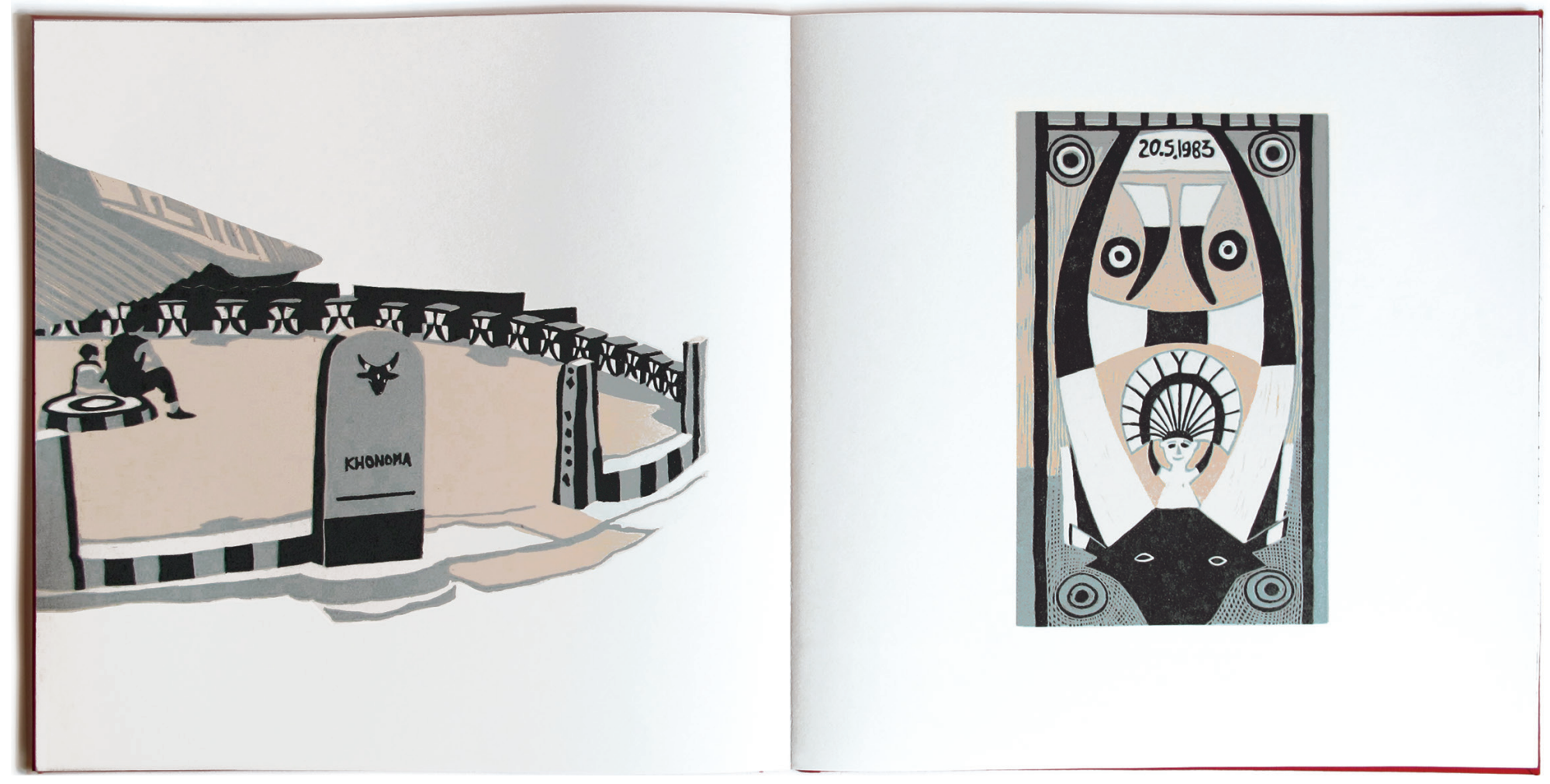

Figure 8: Pages 20 \& 21. Meeting place \& door to Khonoma. Three colour lino cut. 
The Nagas long resistance against British rule culminated in their last stand at the battle of Khonoma in 1879 where the apocalyptic prophecy of Chilsenu, Armageddon, was fulfilled.

\section{Everyone in the whole hill country will fight and be in dispute.}

Men's ears will grow the wrong way round.

People will become so small they can climb chilli plants.

Wooden pestles will put forth leaves.

The dead will rise and the stored grain will fly in the air.

And men will run about to catch it for their food.

A white pillar commemorates the deputy commissioner and his soldiers who died there.

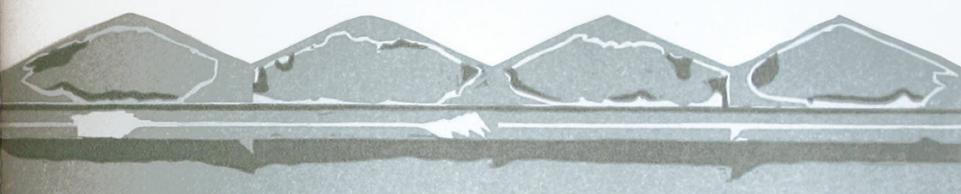

G.H.DAMANT M.A.C.S. SUB MAJOR NURBIR SAI LT.H.H. FORBES,44.G.R. MAJOR C.R. COCK,

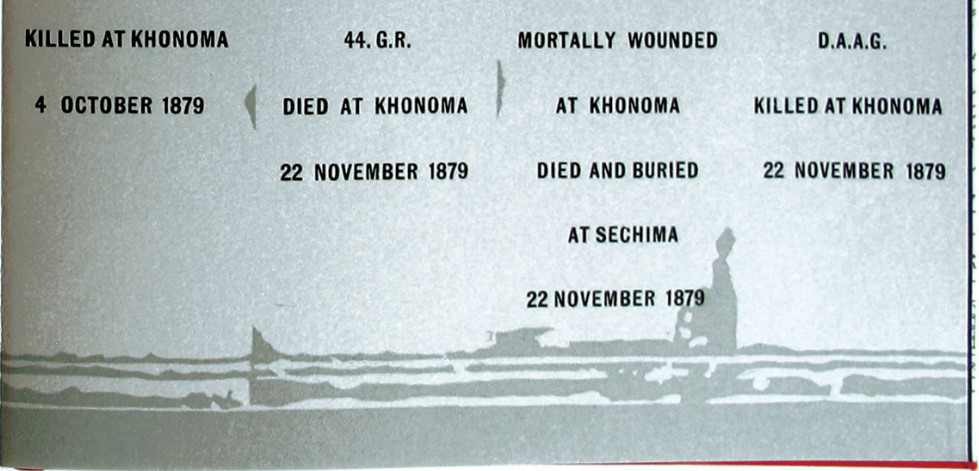

Figure 9: Pages 22 \& 23. Commemorative pillars to soldiers killed in the battle of Khonoma. Two colour lino \& hand set type. 


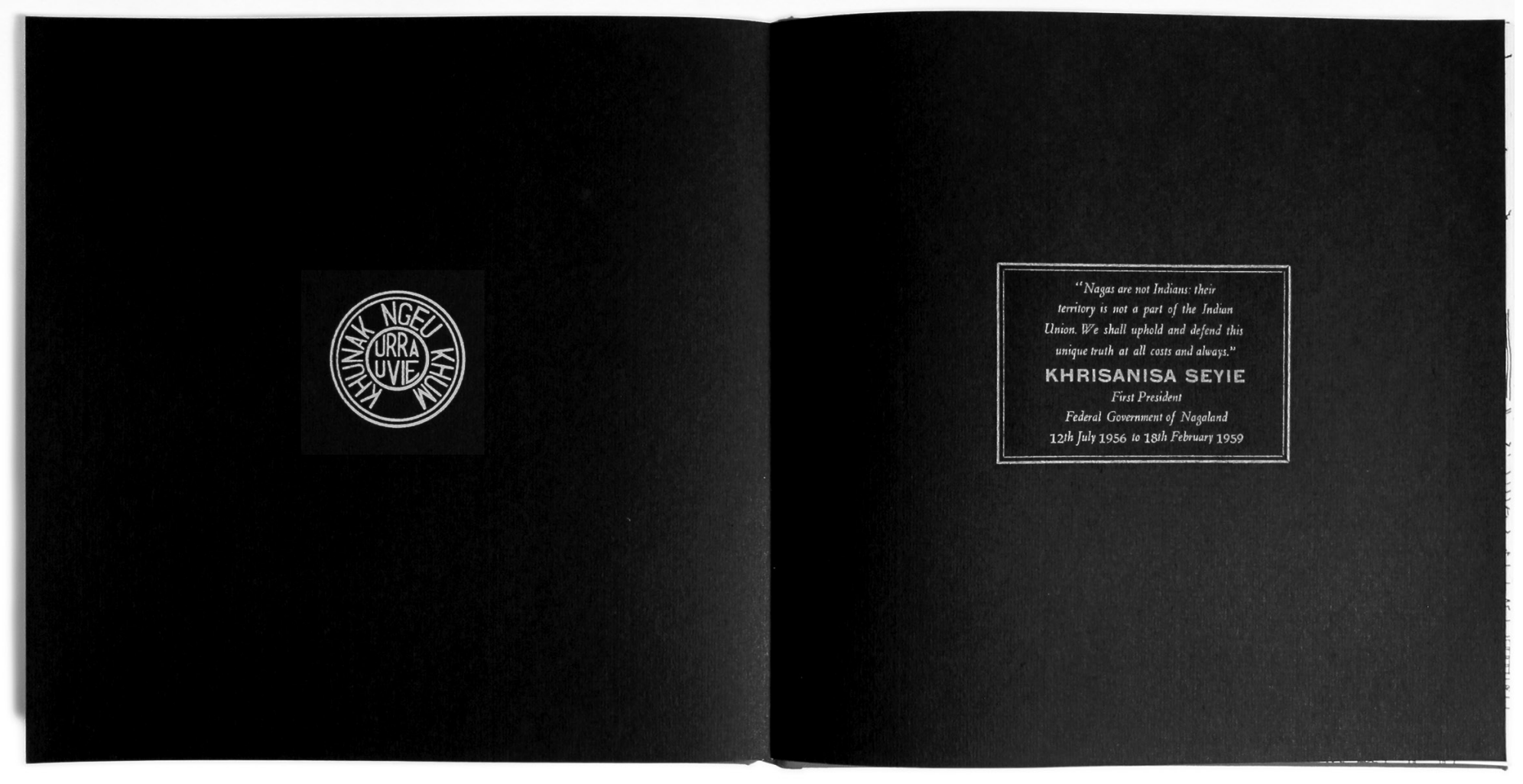

Figure 10: Pages $24 \& 25$ Text taken from a memorial outside Khonoma. Magnesium plate \& hand set type printed white on black paper. 


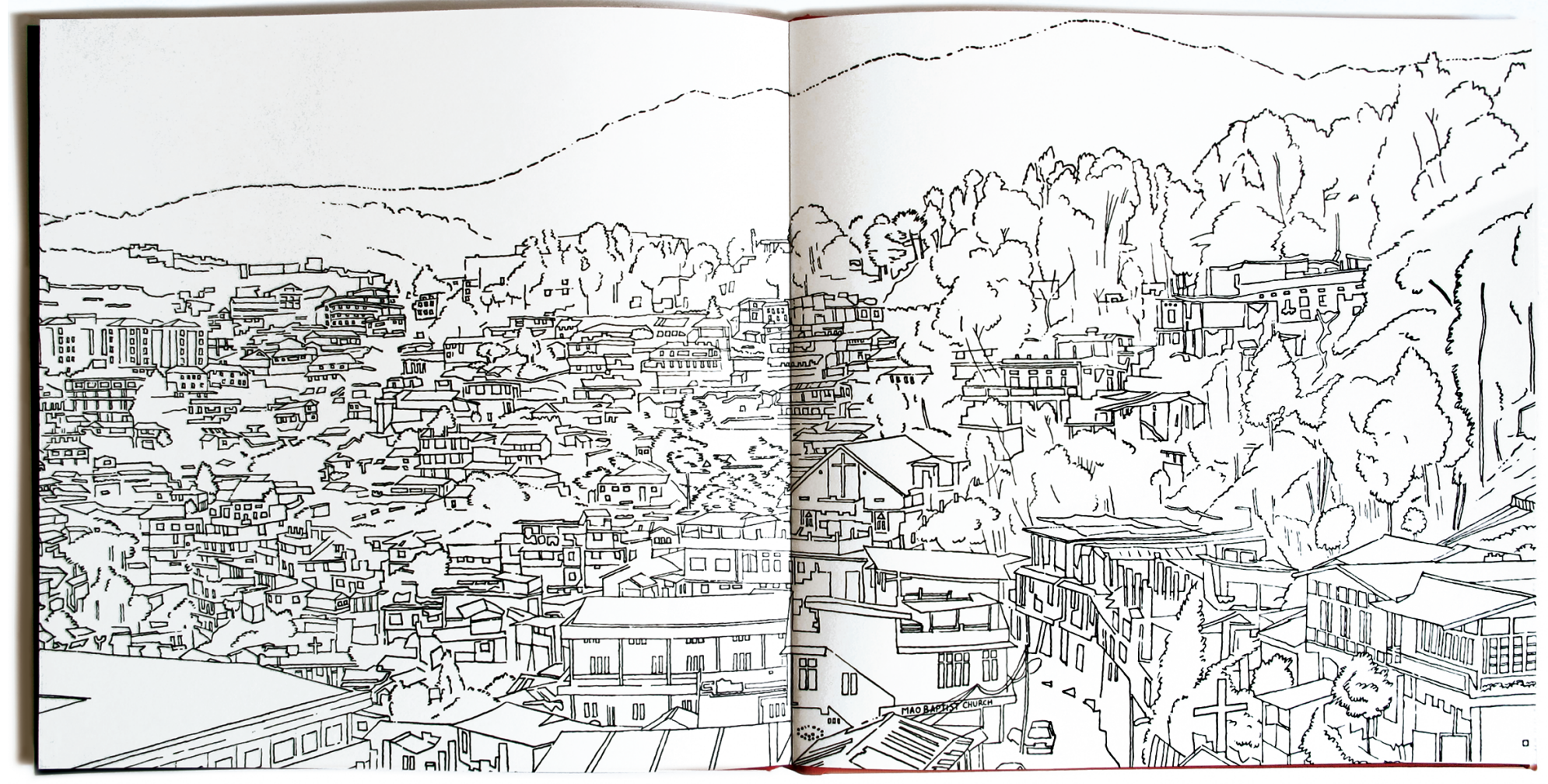

Figure 1l: Pages $26 \& 27$. The view across Kohima. Polymer plate. 

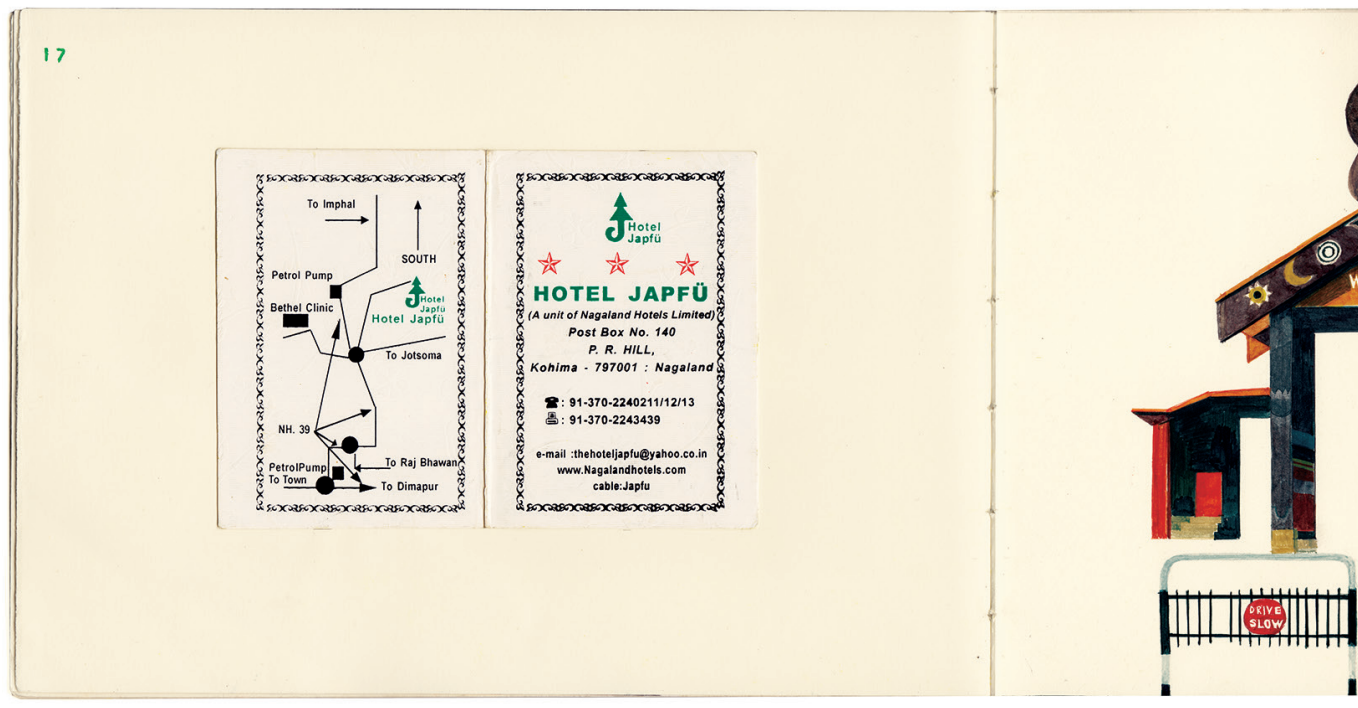

Figure 12: Spread from sketchbook drawn on location. 


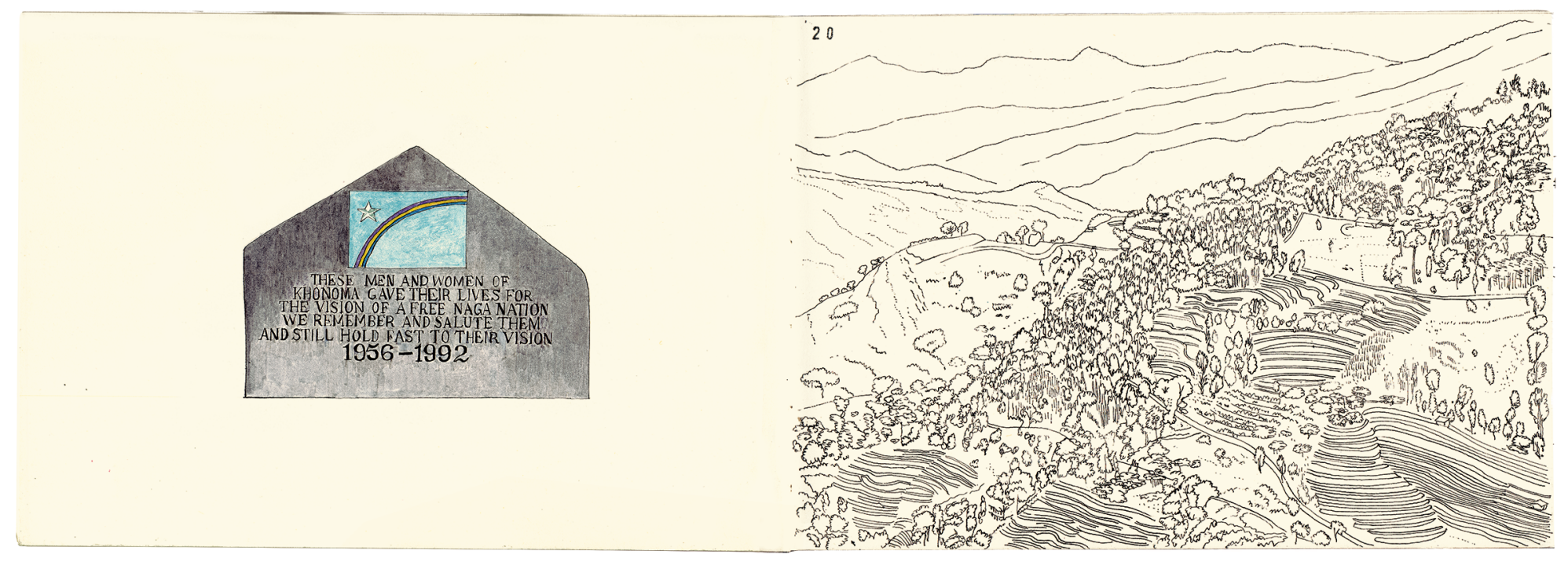

Figure 13: Spread from sketchbook drawn on location. 


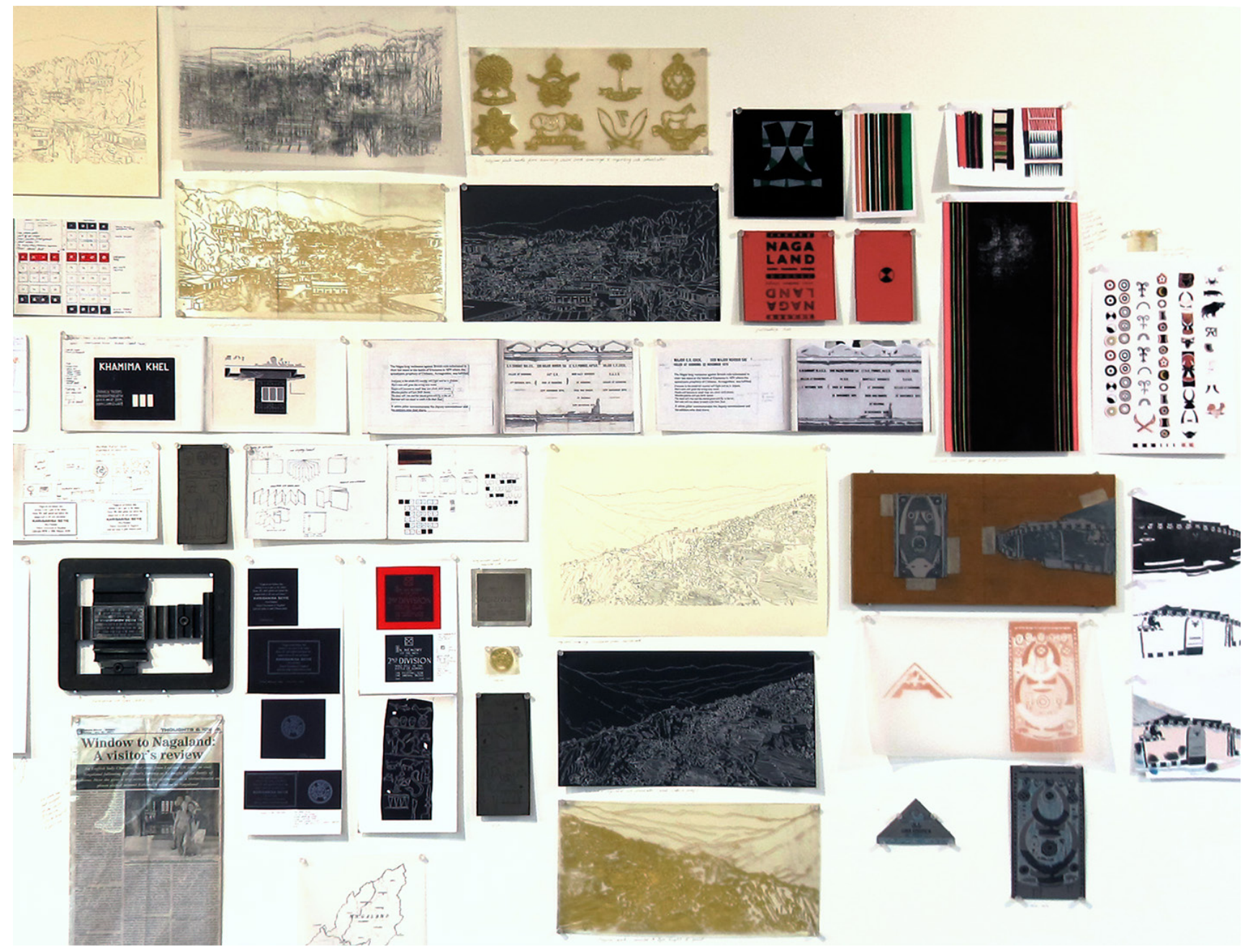

Figure 14: Workings out, plates, cuts \& experiments. 


\section{Suggested citation}

McCauley, C. (2016), 'NAGALAND: Borders, Boundaries, Belonging: Contested spaces and disputed narratives', Journal of Illustration, 3:1, pp. 121-136, doi:10.1386/jill.3.1.121_1

\section{Contributor details}

Christine McCauley is a senior lecturer in Illustration and Visual Communication at the University of Westminster. She studied Illustration at the Royal College of Art and Design at Liverpool College of Art.

Her recent work has been the production of limited edition book works based on her travels in the North East frontier states of India. Recent publications and conference presentations have focused on the role of war art and artists and include the following: Lest we Forget, coordinated by the National Memorial Arboretum and published by the History Press, and 'The tip of the Iceberg', a presentation at the War and Memory Conference, Warsaw.

Contact: Music, Film and Visual Communication, Westminster School of Media, Arts and Design, Harrow Campus, University of Westminster, Northwick Park, HA1 3TP,UK.

Christine McCauley has asserted her right under the Copyright, Designs and Patents Act, 1988, to be identified as the author of this work in the format that was submitted to Intellect Ltd. 